\title{
The Effectiveness of Peer Tutor Learning on the Improvement of Student's Academic and Non- Academic Achievement
}

\author{
W. Banu Oka Sutresna ${ }^{1, *}$ Wiwik Wijayanti ${ }^{2}$ \\ ${ }^{1}$ Master of Educational Management, Faculty of Education, Universitas Negeri Yogyakarta, Indonesia \\ ${ }^{2}$ Department of Educational Management, Faculty of Education, Universitas Negeri Yogyakarta, Indonesia \\ *Corresponding author. Email: wbanuoka.2018@student.uny.ac.id
}

\begin{abstract}
The purpose of this study was to determine the effectiveness of peer tutoring learning in improving the academic and non-academic achievement of students of SMA Negeri 6 Yogyakarta. The objectives of this study were (1) to determine the effectiveness of the peer tutor learning model, (2) the methods used to improve student achievement through peer tutoring, and (3) constraints and solutions in implementing peer tutoring learning. This study uses a qualitative research method with a case study approach. Data collection techniques using observation techniques, documentation study, and interviews. This study obtained three findings, namely: (1) students experienced a very significant increase after participating in peer-to-peer learning. This increase is possible because using the tutoring method, students learn with a supervisor selected from their friends so that the learning process becomes more interesting and fun, (2) the learning method using peer tutors is to collaborate with other students in the form of small groups by providing different material in the group and giving one student the responsibility of fostering the small group, the use of the peer tutor method in the classroom is very useful in the effectiveness and efficiency of the teacher's time as a medium of information and students can be more open to friends to ask questions about the material being taught at that time, and (3) the obstacles faced in the implementation of peer tutoring are that other students treat like ordinary friends so that it is difficult to be given directions, the solution given is to agree with students to comply with the rules given to students who become tutors in groups.
\end{abstract}

\section{Keywords: Peer tutor learning}

\section{INTRODUCTION}

The entire educational process, teaching, and learning activities are the most basic activities. This means that the success or failure of achieving educational goals depends a lot on how the teaching and learning process is designed and carried out professionally. Education in UUSPN No. 20 of 2013 is defined as a conscious and planned effort to create an atmosphere of learning and the learning process so that students actively develop their potential to have religious-spiritual strength, self-control, personality, intelligence, noble character, and skills needed by themselves, society, the nation, and the country.

There are various ways that the teacher must do, so that student learning outcomes can be improved. Learning with the peer tutor method provides the freedom to students to tutor develop methods in explaining the material to friends. However, they too have given the responsibility by the lecturer to explain the subject matter to friends (tutee) who still haven't understood, so that in practice there can be more tutors freely in conveying material by tutee wishes. Facilitated learning conditions by familiar peers will make a tutee follow learning activities more effective because students will have more freedom to spend time learning, learning goals, and mastery expected material. In this regard, the actualization of learning planning and methods must be continuously carried out so that learning objectives can be maximally achieved by optimizing existing resources.

The implementation of the teaching and learning process can be seen from the results obtained in the preliminary research conducted at SMA Negeri 6 Yogyakarta that supporting factors in increasing 
academic and non-academic achievement are influenced by peer tutoring learning, which is a cooperative learning model that is oriented towards student learning activeness at the time. learning in the classroom so that it is expected to provide support to other students to more easily understand the learning material. The effectiveness of this learning model is considered capable of improving student academic and non-academic achievement because; first, some students in the class have higher academic and nonacademic competencies and abilities compared to other students so that students who have more abilities can accompany other students while studying; second, some students do not have the courage or attitude of feeling awkward in asking questions to the teacher so that asking friends is the best alternative, and the third number of students in the class is more so that the teacher has difficulty giving full attention to each of the students. so that the existence of peer tutors can minimize learning difficulties in the classroom.

Peer tutoring and cooperative learning are two of the most researched areas placed under peer learning [1]. Many studies have been conducted to obtain information on the learning process occurring. Much research input has been gathered on the use of peer tutoring at different levels of education. General theoretical perspectives that support use of cooperative learning on performance are motivation, social cohesion, cognitive-developmental perspective and cognitive-elaboration perspective [2]. Peer tutoring is the strategy which writer choose for solving it. Peer Tutoring is effective strategy for students who learn English, it can gives advantages for both because the tutors are friends and their language will be easy to understand each other [3].

Peer tutors can be defined as students who have a deeper ability to understand learning and students who can communicate to deliver learning material, who are in charge of helping students who have difficulty understanding the applications delivered by the teacher during the learning process or lessons related to academic and student academic numbers. Learning assistance provided by peers aims to eliminate students' awkwardness to ask the teacher, and usually, the friend's language is easier to understand than the information conveyed by the teacher directly [3]. The factors that affect student learning can be in the form of internal and external factors. One of the external factors that influence is the teaching method. The existence of student peer tutors is not only used as an object of learning but becomes the subject of learning, namely students are invited to become tutors or learning resources and a place to ask questions for their friends [4]. In this way, students who become tutors perform repetitions and explain the material again so that they become more familiar with each teaching material delivered.

Teaching-learning interaction implies that there are interactive activities of teaching staff who carry out teaching tasks on the one hand, with learning citizens (students, students/learning subjects) who are carrying out learning activities on the other. The interaction between the teacher and the learning community is expected to be a motivational process. That is, how in the interaction process the instructor can provide and develop motivation and reinforcement to the learning community/students so that they can carry out learning activities optimally [4]. In peer tutoring strategy, teachers will choose some students who have good ability in English, they will be tutors for their friends. The tutors not only have to teach but also have to lead their friends in discussion or learning [5].

The Peer Tutor learning model is carried out by empowering the ability of students who have high absorption, the student teaches the material to his friends who do not understand so that it fulfills all learning completeness. Therefore, it is hoped that with peer tutors, less active students will become active, because they are not ashamed to ask questions and express opinions freely to their peers. Other research results explain that the cooperative learning system is a system that provides opportunities for students to work together with fellow students in structured tasks.

One of the learning models that are thought to be applied to facilitate students is to apply the cooperative learning model which refers to various teaching methods where students work in small groups to help each other in learning material [7]. In a cooperative class, students are expected to help each other, discuss and argue with each other, to hone the knowledge they have mastered at that time, and close the gaps in each other's understanding. The peer tutor learning system is one of the methods that can be an alternative in the learning process at school and needs to get attention and choice for teachers in teaching a subject. Peer tutors are a learning model carried out by students in a class or a class appointed by the teacher with various considerations. A student is often easier to accept information or knowledge provided by peers or other friends because they do not feel awkward or embarrassed to ask questions and discuss. A characteristic of peer tutoring is the clear and specific role set for tutor and tutee (Topping, 2005). In peer tutoring, a member of a group is regarded as more knowledgeable than others and knowledge is transmitted in unidirectional manner to novice [6]. 
Student's active learning through discussion, problem solving, problem posing and presentation. Presentation skills are vital to achieving success in all aspects of daily life. One way that can be done to improve students' communication skills is by implementing a relevant learning model to be applied by the teacher. The learning model that should be applied is the peer tutor cooperative learning model which provides opportunities for students to construct their knowledge so that students find it easier to understand the concepts being taught and communicate their ideas in oral and written form through peers [7].

In learning, students are actively involved by asking questions and expressing opinions that are carried out individually. What students do not understand and to solve problems, solutions can be obtained from other students. Guidance of teachers and researchers by clarifying the answers of students who convey their opinions. If there are students who have learning difficulties, other students feel responsible for helping them. As a result, students are trained to solve problems on their own. With this twoway interaction, students understand the material faster before there is an explanation from the teacher and solve the questions given by the researcher who acts as a teacher at the end of each subject matter action. There are five elements in cooperative learning, namely; (a) positive interdependence, (b) individual responsibility, (c) face to face, (d) communication between members, evaluation of group processes. The ten points mentioned as elements and elements in cooperative learning above are an important part for the teacher to copy when forming student learning groups. Not all of these may be fulfilled, but these are signs when establishing cooperative learning. The advantage of these facts and elements is that the teacher becomes more selective and focused when forming study groups.

Many advantages have been demonstrated through the strategy of peer tutoring; above all, the benefits have been based on the motivation to study, increment in average grades; in addition to being involved values such as solidarity and other skills such as improved communication [8].

Peer learning refers to a teaching method where students work together in small groups helping each other in learning. Peer tutors are a learning model carried out by students in a class or a class appointed by the teacher with various considerations. A student is often easier to accept information or knowledge provided by peers or other friends because they do not feel awkward or embarrassed to ask questions and discuss. In the application of peer tutoring, it will build a cooperative, not competitive, group learning atmosphere [9]. Besides, the peer tutor learning method can also minimize the dominance of the teacher in learning and the teacher acts as a facilitator to improve student learning skills and abilities [10].

The learning model that should be applied is the peer tutor cooperative learning model which provides opportunities for students to construct their knowledge so that students find it easier to understand the concepts being taught and communicate their ideas in oral and written form through peers. There is a significant effect of the peer tutoring method on the motivation to learn the mathematics of high school students. This means that the application of the peer tutor learning method will increase the motivation to learn the mathematics of high school students. Peer tutors are the recruitment of one student to provide one by one instruction to other students, in completing the assignment given through the participation of the tutor and tutee role. The tutor has more skills than the tutee, but in some variations of the tutorial, the distance of knowledge between the tutor and the tutee is minimal [11].

This method is also able to play a role in measuring the level of students in the learning process related to three aspects of learning objectives, namely cognitive aspects, affective aspects, psychomotor aspects. This learning model can facilitate students who have different abilities. Students who have better knowledge regarding the material being studied can show concern and responsibility for their friends. This will enable these students to share and care for their underprivileged friends and foster a sense of mutual responsibility in learning, as well as foster selfconfidence. Learning methods like this can make students learn from their peers and it is hoped that it will improve learning achievement both individual and classical achievement [12].

Various kinds of obstacles that are caused when carrying out the learning process are experienced by students and teachers themselves in carrying out the learning process in the classroom. The obstacles that students often experience include: (a) students forget the prerequisite material to proceed to the next material, (b) students lack confidence in expressing ideas, (c) students have difficulty expressing ignorance, and (d) students feel bored in the learning process. Other obstacles experienced by teachers include: (a) lack of alternative media and learning resources available in schools, (b) lack of knowledge about learning models, (c) lack of good classroom management, (d) students pay less attention to a 
teacher explain, and (e) lack of time to take individual approaches for students. The teaching strategy is a method that is implemented by the teacher in the learning process by focusing on the learning situation to achieve predetermined goals. A good teaching strategy is a strategy that requires students to be active in thinking and acting independently and creatively in developing the material they have mastered [13].

The principle of peer tutoring learning there are four criteria for becoming a peer tutor, among others, a) the tutor helps students or students who have difficulties based on the teacher's instructions, b) the student or student selected as a tutor should pay attention to the aspect of ability in mastering material and the ability to help others, c) in practice, these tutors can help their friends either individually or in groups according to the teacher's instructions, d) the tutor can act as a leader in group activities, in certain cases, he can act as a substitute for the teacher. The influence of the peer tutors method on teaching and learning activities can run effectively and efficiently if a teacher pays attention to and implements several steps in implementing peer tutoring.

In determining who will be the tutor, your consideration is needed. The steps are as follows: (a) students who are used as tutors have superior intelligence than other students, (b) have skills in receiving lessons that are taught by the teacher, (c) have the awareness to help friends, (d) able to collaborate with students, (e) have high motivation to make the tutor group the best, (f) can be accepted and liked by students who receive peer tutoring programs so that students do not have fear or are reluctant to ask him questions and are diligent, (g ) not being arrogant to fellow friends, and (h) having sufficient creativity to provide guidance, namely being able to explain lessons to his friends.

The use of this approach in learning sometimes the teacher has to adapt to the conditions, circumstances of students, and the classroom atmosphere. In teaching teachers rarely use one method, because they realize that all methods have advantages and disadvantages. Some of the advantages of peer tutoring learning methods including (a) there is an atmosphere of closer and closer relationship between students and peer tutors, (b) for the tutors themselves this activity is enrichment and increases learning motivation, (c) is efficient and can be more lots to help, and (d) can increase the sense of trust responsibility. And then, there are several weaknesses in the peer tutor learning method, including: (a) students who are selected as peer tutors and perform well do not necessarily have a good relationship with the students being assisted, (b) students who are selected as peer tutors may not necessarily be able to convey material well, and (c) students who are assisted often learn less seriously [14].

Discussed the use of peer tutoring for improvement student's confidence, presentational and professional skill. The background of the study is based on connection between peer tutoring and students' confidence may be implied in this research because that link has not been explored by the literature [15].

From the description above it can be concluded that the peer tutor learning pattern is expected to be able to build cooperation and be more motivated in learning because peer tutors know more about the conditions of their friends in learning because the peer tutoring method applied in class can improve the quality of learning and shorten the time in conveying information to students as a whole.

\section{METHOD}

Discussed about using peer tutoring technique to improve student's reading comprehension in CAR (Classroom Action Research) [16]. The writer wanted to know if using peer tutoring technique to improve student's reading comprehension and describing what happened with the class when peer tutoring technique is conducted in reading class. The research method which the writer used are quantitative and qualitative.

The steps of qualitative research are selecting problems, gathering relevant materials, determining strategies and developing instruments or informants in research, collecting data, interpreting data, and reporting research results. Subjects were informants or resource persons in this study who were teachers and students as data sources related to peer tutor research in the classroom. The object of this research refers to mathematics which is very important in using the peer tutoring method because the teacher finds it more difficult to convey messages to the number of students in the class. Collecting research data using field observation techniques, interviews, and documentation studies. The data analysis was carried out by organizing the data, analyzing the data by the research theme, and finding patterns related to the peer tutor learning model in the classroom [17].

This research was conducted at SMA Negeri 6 Yogyakarta. The reason for using this method is because this research is directly related to the object to be studied, namely humans (social). In the book Basics of Qualitative Research, researchers who deal directly with humans (socially) must use a qualitative approach. This is done for the reasons: (a) the 
researcher must go into the field to discover what happened, (b) the relevance of data-based theory for the development of disciplines and social action, (c) the complexity of phenomena and human actions, (d) the belief that humans are actors who play an active role in responding to problematic situations, (e) awareness that humans act based on meaning, (f) understanding that meaning is redefined and redefined through interaction, $(\mathrm{g})$ sensitivity to nature will reveal an event, (h ) awareness of the relationship between conditions (structures), actions (processes) and consequences.

\section{RESULTS AND DISCUSSION}

Based on the results of research conducted at SMA Negeri 6 Yogyakarta, there are several findings of the effectiveness of peer tutoring in improving student academic and non-academic achievement. The findings obtained are: (a) The average student has experienced a very significant increase in both academic and non-academic fields (such as extracurricular activities, sports, and the arts) after participating in peer tutoring. This increase is possible because using the tutoring method, students learn with a supervisor selected from their friends so that the learning process becomes more interesting and fun. The use of the peer tutor method in the learning process can be an option in teaching students that are more difficult at school because it affects student learning outcomes. Besides being easy to apply in the learning process, the teacher divides students into several groups, each group consisting of 4-5 students. Each group has one person who is sure to become a tutor on the channel. The tutors are students who are ranked in the top 10 in the class. The peer tutor method provides students with the motivation to learn cognitive, affective, and psychomotor so that student learning outcomes increase optimally. (b) Learning with the peer tutor method gives freedom to students who become tutors to develop methods of explaining material to their friends. However, they are also given the responsibility by the teacher so that they can explain the subject matter to friends who still don't understand so that in practice the tutor can more freely deliver the material as desired. Learning conditions that are facilitated by familiar peers will make students take part in learning activities more effective because students will have more flexibility in managing learning time, learning objectives, and target mastery of the expected material. the benefits of peer tutoring learning are the enthusiasm for team building, psychological comfort because they work with peers, can improve social competence, communication skills, students are more confident, direct interaction between students will encourage active learning, and can improve learning outcomes. (c) Obstacles faced in implementing tutor learning Peers are other students who treat like ordinary friends so that it is difficult to be given directions, the solution given is to agree with students to obey the rules given to students who are tutors in the group. Thus, teachers must be ready and willing to spend more time training tutors. Besides, there needs to be an increase in the scope of subject matter to be studied in groups, so that tutorial activities can run more interactively and effectively.

\section{CONCLUSION}

This study concludes that learning through peer tutors is effective in improving student learning in class and has an impact on improving students' academic and non-academic achievement. Peer tutor learning methods are proven to contribute to the emergence of learning behavior based on the characteristics of the tutor and students. Based on the findings of this study, the researcher suggests that teachers in schools facilitate learning models that can improve student regulation in their learning, namely through peer tutoring methods. This peer tutor learning method will increase the level of student understanding of the given learning assignments. This can be seen when doing group work and presenting it in front of the class, students can explain it well and can answer questions from students and teachers. This learning method is faster than the control group with conventional learning models. However, every learning model that is carried out in class must exist along this path, not too disturbing the learning process as a whole. Some of the things that make sense when applying the peer tutoring method are that it is difficult to determine which tutors are based on test scores before the action, it is difficult to find students who have high academic abilities, it is difficult to measure time well. The strategies that can minimize this supervision through the selection of tutors can be done by looking at the value of their daily exercises and asking for input from other teachers as an alternative consideration, the assessment can go according to plan, it would be nice for each step that is timed, the teacher must prepare enough time to be able to prepare tutors through tutorial guidance properly so that the appointed tutor thoroughly understands the material that will be shared with other students.

\section{REFERENCES}

[1] K.J. Topping, The Effectiveness Peer Tutoring in Further and Higher Education: A Typology and Review of The Literature, Higher Education 
32(3) (1996) 321-345. DOI: https://doi.org/10.1007/BF00138870

[2] R.E. Slavin, Research on Cooperative Learning and Achievement: What We Know, What We Need to Know, Contemporary Educational Psychology 21(1) (1996) 43-69. DOI: https://doi.org/10.1006/ceps.1996.0004

[3] Herrell, Jordan. Fifty Strategies for Teaching English Language Learners, Pearson Education, 2004.

[4] A. Nurkhin, Efektivitas Pembelajaran Tutor Sebaya dalam Pembelejaran Akuntansi Biaya I, Jurnal Pendidikan Ekonomi Dinamika Pendidikan 8 (1) (2013) 26-37. DOI: https://doi.org/10.15294/dp.v8i1.4896

[5] L. Cleary, I. O'Sullivan, Peer Tutoring in Academic Writing: The Infectious Nature of Engagement, Journal of Academic Writing 4(1) (2014) 52-65. DOI: https://doi.org/10.18552/joaw.v4i1.72

[6] S.J. McCarthey, S. McMahon, From convention to invention: Three approaches to peer interactions during writing, in: R. HertzLazarowitz, N. Miller (Eds.), Interaction in Cooperative Groups: The Theoretical Anatomy of Group Learning, Cambridge University Press, Cambridge, 1992, pp. 17-35.

[7] J. Harper, Presentation skills, Industrial and Commercial Training. 36(2) (2004) 125-127. DOI: https://doi.org/10.1108/00197850410532140

[8] M.A. Melero, P. Fernandez, Peer Learning: Social Interaction in Educational Contexts, 21st Century, 1995.

[9] R.K. Yin, Case Study Research: Design and Method (5 $5^{\text {th }}$ ed.), Sage Publication, 2014.

[10] Anselm, The Major Works, Oxford University Press, 2015.

[11] J.W. Creswell, Research Design Pendekatan Kualitatif, Kuantitatif dan Mixed, Pustaka Pelajar, 2017.

[12] S. Sungur, C. Tekkaya, Effect of Problem Based Learning and Traditional Instruction on Self Regulated Learning, The Journal of Education Research 99(5) (2006) 307. DOI: https://doi.org/10.3200/JOER.99.5.307-320

[13] M.M. Alwi, Pengaruh metode tutor sebaya terhadap motivasi dan prestasi belajar matematika siswa SMA, M. S. thesis, Fakultas Psikologi, Universitas Gadjah Mada, Yogyakarta, 2009.
[14] Suryono, Amin, Pengajaran Remedial untuk SPG, Depdikbud, 1994.

[15] K. Arrand, Peer Tutoring, Journal of Pedagogi Development 4(1) (2014) 47-61.

[16] R.E. Slavin, Cooperative Learning, United States of America Printed Press, 1995.

[17] S.R. Brigitta, Using peer tutoring technique to improve student's reading comprehension, M.Ed. Thesis, English Education Department, Graduate School, Universitas Sebelas Maret, Surakarta, 2011. 